\title{
Lin28 sustains early renal progenitors and induces Wilms tumor
}

\author{
Achia Urbach,, ${ }^{1,2,3,4}$ Alena Yermalovich, ${ }^{1,2,3,4}$ Jin Zhang, ${ }^{1,2,3,4}$ Catherine S. Spina, ${ }^{1,2,3,4}$ Hao Zhu, ${ }^{5,6,7}$ \\ Antonio R. Perez-Atayde, ${ }^{8}$ Rachel Shukrun, ${ }^{9,10}$ Jocelyn Charlton, ${ }^{11}$ Neil Sebire, ${ }^{12}$ William Mifsud, ${ }^{12}$ \\ Benjamin Dekel, ${ }^{9,10}$ Kathy Pritchard-Jones, ${ }^{11}$ and George Q. Daley ${ }^{1,2,3,4,13}$ \\ ${ }^{1}$ Stem Cell Transplantation Program, Division of Pediatric Hematology/Oncology, Children's Hospital Boston, Boston, \\ Massachusetts 02115, USA; ${ }^{2}$ Howard Hughes Medical Institute, Boston, Massachusetts 02115, USA; ${ }^{3}$ Department of \\ Biological Chemistry and Molecular Pharmacology, Harvard Medical School, Boston, Massachusetts 02115, USA; ${ }^{4}$ Harvard \\ Stem Cell Institute, Boston, Massachusetts 02115, USA; ${ }^{5}$ Children's Research Institute, ${ }^{6}$ Department of Pediatrics, ${ }^{7}$ Department \\ of Internal Medicine, University of Texas Southwestern Medical Center, Dallas, Texas 75390, USA; ${ }^{8}$ Department of Pathology, \\ Boston Children's Hospital, Boston, Massachusetts 02115, USA; ${ }^{9}$ Pediatric Stem Cell Research Institute, ${ }^{10}$ Division of Pediatric \\ Nephrology, Sheba Medical Center, Sackler School of Medicine, Tel Aviv University, Tel Aviv 52621, Israel; ${ }^{11}$ Institute of Child \\ Health, University College London, London WC1H 0AJ, United Kingdom; ${ }^{12}$ Department of Histopathology, Camelia Botnar \\ Laboratories, Great Ormond Street Hospital for Children, London WC1N 3JH, United Kingdom
}

Wilms Tumor, the most common pediatric kidney cancer, evolves from the failure of terminal differentiation of the embryonic kidney. Here we show that overexpression of the heterochronic regulator Lin28 during kidney development in mice markedly expands nephrogenic progenitors by blocking their final wave of differentiation, ultimately resulting in a pathology highly reminiscent of Wilms tumor. Using lineage-specific promoters to target Lin28 to specific cell types, we observed Wilms tumor only when Lin28 is aberrantly expressed in multiple derivatives of the intermediate mesoderm, implicating the cell of origin as a multipotential renal progenitor. We show that withdrawal of Lin28 expression reverts tumorigenesis and markedly expands the numbers of glomerulus-like structures and that tumor formation is suppressed by enforced expression of Let-7 microRNA. Finally, we demonstrate overexpression of the $L I N 28 B$ paralog in a significant percentage of human Wilms tumor. Our data thus implicate the Lin28/Let-7 pathway in kidney development and tumorigenesis.

[Keywords: kidney development; Wilms tumor; Lin28]

Supplemental material is available for this article.

Received December 24, 2013; revised version accepted March 25, 2014.

Wilms tumor, a pediatric kidney cancer affecting one in 10,000 children in North America, arises from the failure of embryonic nephrogenic cells to undergo terminal differentiation (Rivera and Haber 2005). The development of the kidney is a complex process that requires reciprocal inductive interactions between the ureteric bud (UB) and metanephric mesenchyme (MM), which leads to proliferation and expansion of the primitive cap mesenchyme (CM) (Grobstein 1955, 1956; Hatini et al. 1996; Davidson 2009). The CM cells differentiate into mature nephrons by a mesenchymal-to-epithelial transition (MET). As they also possess self-renewal capacity, CM cells represent embryonic kidney stem cells (Kobayashi et al. 2008; Pleniceanu et al. 2010). CM cells proliferate and differentiate in the outer nephrogenic zone of the kidney until the second postnatal day in mice (Hartman et al. 2007) and

${ }^{13}$ Corresponding author

E-mail george.daley@childrens.harvard.edu

Article published online ahead of print. Article and publication date are online at http://www.genesdev.org/cgi/doi/10.1101/gad.237149.113. the 36th week of gestation in humans (Hinchliffe et al. 1991), after which time all remaining CM cells synchronously differentiate to establish the final number of nephrons in the adult kidney (Hartman et al. 2007). Wilms tumor shares histological features with the developing kidney and is frequently associated with persistent areas of embryonic tissue known as nephrogenic rests, which contain blastemal cells with varying degrees of differentiation (Rivera and Haber 2005).

Lin28 is an RNA-binding protein that regulates gene expression via two different mechanisms: one that blocks the processing of the Let-7 family of microRNAs (miRNAs) (Heo et al. 2008; Newman et al. 2008; Rybak et al. 2008; Viswanathan et al. 2008) and another that involves direct

(C) 2014 Urbach et al. This article is distributed exclusively by Cold Spring Harbor Laboratory Press for the first six months after the full-issue publication date (see http://genesdev.cshlp.org/site/misc/terms.xhtml). After six months, it is available under a Creative Commons License (AttributionNonCommercial 4.0 International), as described at http://creativecommons. org/licenses/by-nc/4.0/. 
binding to a wide array of mRNA targets (for review, see Shyh-Chang and Daley 2013). The Let-7-dependent mechanism entails binding to the terminal loop of pri/pre-Let-7 miRNAs, which prevents their maturation and thus enables the translation of genes that are suppressed by Let- 7 miRNAs (Viswanathan et al. 2008). Oncogenes such as $K$-Ras and $c$-Myc are prominent Let-7 targets (Viswanathan and Daley 2010). In mammals, Lin28A and its closely related paralog, Lin28B, are highly expressed in pluripotent cells, where they play an important role in the maintenance of self-renewal and proliferation (ShyhChang and Daley 2013). Both Lin28 proteins are highly expressed in early embryonic development but become down-regulated over time, while levels of mature Let-7 family members rise as stem cells differentiate into specialized tissue types (Viswanathan and Daley 2010). Overexpression of LIN28 is common in various tumor types and facilitates cellular transformation (Viswanathan et al. 2009). Lin28 also promotes reprogramming of somatic cells into induced pluripotent cells (Yu et al. 2007).

Given that Lin28 is highly active in embryonic tissues and was originally described as a heterochronic gene that regulates developmental timing in Caenorhabditis elegans (Ambros and Horvitz 1984; Moss et al. 1997), we hypothesized that Lin28 overexpression might play a role in pediatric tumor formation by altering the timing of tissue differentiation and organogenesis during embryonic development. Indeed LIN28A overexpression has been implicated in type II germ cell tumors (Gillis et al. 2011), which result from a failure of differentiation of primordial germ cells (PGCs) (Oosterhuis and Looijenga 2005), while $L I N 28 B$ has been linked to neuroblastoma (Diskin et al. 2012), a pediatric tumor derived from neural crest tissues that fail to complete their differentiation program (Maris 2010; Molenaar et al. 2012). Last, we reported previously that in rare cases of human Wilms tumor, $L I N 28 B$ overexpression is caused by translocation at the LIN28B locus (Viswanathan et al. 2009). Here we describe a novel murine model of Wilms tumor caused by enforced overexpression of Lin28 during embryonic kidney development and demonstrate by immunohistochemistry that LIN28B is overexpressed in up to $30 \%$ of cases of human Wilms tumor. These data, together with recent insights from whole-genome sequencing of Wilms tumor, implicate defects in miRNA regulation as a major mechanism of kidney tumorigenesis.

\section{Results}

Lin28 overexpression during embryonic kidney development leads to Wilms tumor

Previously, we and others have shown that LIN28 plays an important role in germ cell development (West et al. 2009; Shinoda et al. 2013a) and is associated with human germ cell tumors (Gillis et al. 2011; Murray et al. 2013). Thus, we endeavored to overexpress Lin28 in PGCs by crossing mice containing a Lox-stop-Lox-Lin28a cassette (LSL-Lin28a) (Supplemental Fig. S1A) with mice carrying a Vasa-Cre transgene, which we anticipated would express
Cre in PGCs when transmitted paternally, allowing us to test the potential for Lin28 to induce germ cell tumors (Gallardo et al. 2007). Contrary to expectations, however, the cross between a LSL-Lin28a female and VasaCre male did not yield the predicted germ cell phenotype (zero out of 50) but unexpectedly produced renal tumors in $10 \%$ of the offspring (five out of 50; four bilateral and one unilateral) (Fig. 1A, top left). Tumors expressed the Lin28a transgene, apparently a consequence of aberrant "leaky" activation, whereas normal kidneys showed no transgene expression (Fig. 1B). Crosses of LSL-Lin28a males with females carrying the Vasa-Cre allele resulted in constitutional overexpression in all tissues by virtue of Cre expression in oocytes (Gallardo et al. 2007) and perinatal lethality. Interestingly, the kidneys of transgenic embryonic day 18.5 (E18.5) embryos were larger than the kidneys of their littermate controls and contained fewer mature proximal tubules (Supplemental Fig. S1B). When we harvested the kidneys from E18.5 transgenic and control embryos and transplanted them under the kidney capsule of immunodeficient mice, tumors developed in a high percentage of recipients (seven out of 10) (Fig. 1A, top right panel; Supplemental Fig. S1C). No tumors formed in transplant recipients of control kidneys (zero out of nine). Analysis of tumor gene expression (Fig. 1C) and histology (Fig. 1D) indicated that the Lin28a-derived tumors were highly similar to human Wilms tumor.

Previously, we reported two cases of human Wilms tumor in which LIN28B was overexpressed as a result of chromosomal translocation (Viswanathan et al. 2009). To determine whether human $L I N 28 B$ overexpression would replicate Wilms tumor formation in mice, we engineered a transgenic strain that afforded spatial and temporal control of human LIN28B (or mouse Lin28a) overexpression by crossing the Rosa26-Lox-stop-Lox-rtTA allele with the Col1A1-TRE-LIN28B allele (Lox-TetOn-LIN28B mice) (Supplemental Fig. S1D; Zhu et al. 2010). To achieve global LIN28B overexpression in the developing and/or adult kidney, we crossed Lox-TetOn-LIN28B mice with Wt1Cre mice (Zhou et al. 2008), as Wt1 is expressed in the intermediate mesoderm (Huff 2011), the origin of the metanephric kidney (Davidson 2009). All Wt1Cre-LIN28B mice (15 out of 15) developed kidney tumors (Fig. 1A, bottom panel) within the first $2 \mathrm{wk}$ of life when exposed to doxycycline (Dox) induction during embryonic development (E0, E14.5, or even as late as E18.5) (see below). Importantly, the histology of the LIN28B-derived tumors was similar to Lin28a-derived tumors (Fig. 1D). Taken together, these results establish that overexpression of either murine Lin28a or human LIN28B during kidney development in transgenic strains of mice leads to kidney tumor formation that is highly reminiscent of human Wilms tumor (Fig. 1E).

\section{Lin28 overexpression sustains the CM cells in the adult kidney}

During kidney development, the nephronogenic progenitor cells of the CM cells differentiate into pretubular epithelial aggregates by a MET at around E12.5 (Rivera 
A

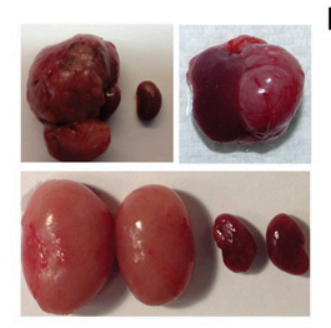

D

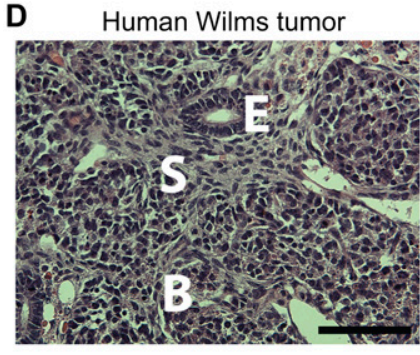

E
B

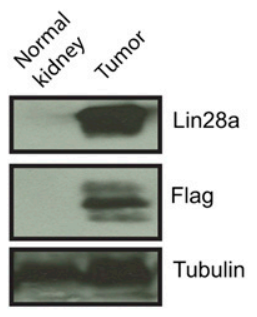

Lin28a derived tumor

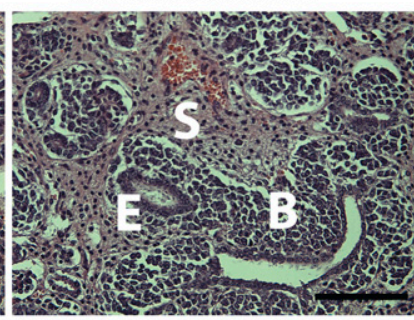

C

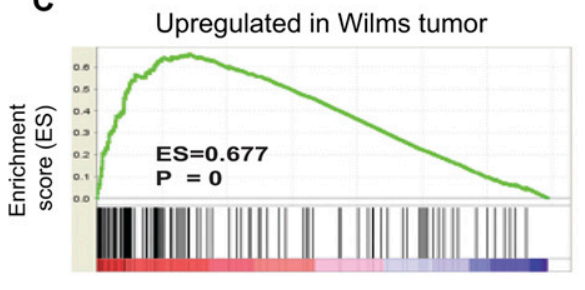

LIN28B derived tumor

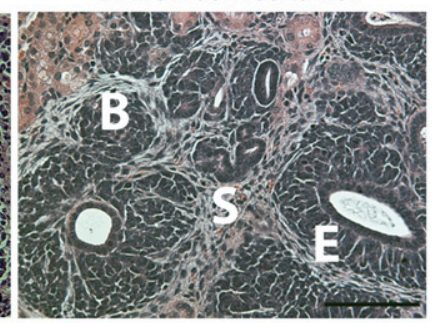

Tissue specific over-expression

Global

No Tumor

over-expression

Tumor

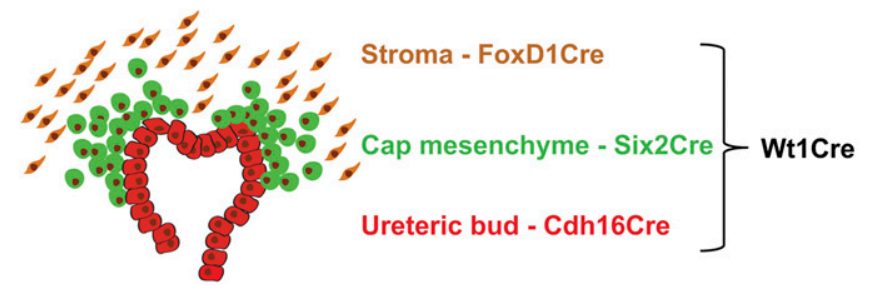

Figure 1. Lin28 overexpression in embryonic kidneys leads to Wilms tumor. (A) Kidney tumors as a result of Lin28 overexpression in the kidney. (Top left panel) Renal tumor in a 17-wk-old kidney from the crossing between a LSL-Lin28a female and a VasaCre male. The smaller kidney is the normal kidney from the opposite side in the same mouse. (Top right panel) Tumor derived by transplantation of a Lin28a-overexpressing kidney (from the crossing between a LSL-Lin28 a male and a VasaCre female) under the kidney capsule of an immunodeficient mouse $17 \mathrm{wk}$ post-transplantation. (Bottom panel) LIN28B-derived tumors in 3-wk-old kidneys (Dox induction [1g/L] from E0). (B) Western blot analysis of tumors and age-matched normal kidneys with antibodies against Lin28a, Flag, and Tubulin. The expression of the Flag tag shows activation of the transgenic Lin28a in the tumor. $(C)$ Gene set enrichment analysis (GSEA) of microarray data from Lin28a-derived tumors and control kidneys showing statistically significant up-regulation of "Wilms tumor signature genes" in the tumor compared with the control. $(D)$ Typical histology of a human Wilms tumor, a Lin28a-derived tumor, and a LIN28B-derived tumor. The tumors are triphasic and contain structures of blastema (B), epithelium (E), and mesenchymal stromal (S) cells. Bar, $100 \mu \mathrm{m}$. (E) Schematic representation of the UB and CM cells, which normally exist in the nephrogenic zone of the mouse kidney only until P2. Global Lin28a or LIN28B overexpression in the developing kidney leads to a pathology similar to human Wilms tumor. However, lineage-specific overexpression did not cause renal tumor formation (see below).

and Haber 2005). Normally, a balance between differentiation and proliferation of CM cells is sustained in the nephrogenic zone of the developing kidney until postnatal day 2 (P2), after which time all CM cells undergo a terminal wave of differentiation (Rumballe et al. 2011). In contrast to normal kidneys, the Lin28-derived tumors continue to sustain proliferating CM cells, as evidenced by the expression of CM-specific transcription factors (e.g., Six2, Cited1, and Eya1) and Ki67 staining (Fig. 2A,B; Supplemental Fig. S2A). Moreover, H\&E (Fig. 2C) and immunofluorescence (Fig. 2D; Supplemental Fig. S2B,C) staining of the tumors demonstrates that the tumor consists of keratin8-positive UB cells surrounded by Six2positive CM cells, similar to the structures that normally exist in the nephrogenic zone of the developing kidney. Taken together, these data indicate that Lin28 overexpres- sion prolongs the timing of kidney development, sustaining proliferation of the CM cells into adulthood. Interestingly, the CM cells of the tumor retain their differentiation capacity, as evident by gene expression for markers of epithelialization, such as Wnt4 and CDH6 (K-cadherin) (Fig. 3A; Supplemental Fig S3A); gross histology (Fig. 3B; Supplemental Fig S3B); and histologic staining for Lotus tetragonolobus lectin (LTL), a specific marker for mature proximal tubules (Fig. 3C). Importantly, the fact that the differentiated epithelial cells are Flag-positive (Supplemental Fig. S3C) indicates that these cells are indeed derived from the Lin28-overexpressing cells. Furthermore, the Lin28-derived tumors also contain structures resembling differentiated glomeruli (Supplemental Fig. S3D,E). Thus, the CM cells within the tumor retain a differentiation capacity that recapitulates normal kidney development. 
Urbach et al.

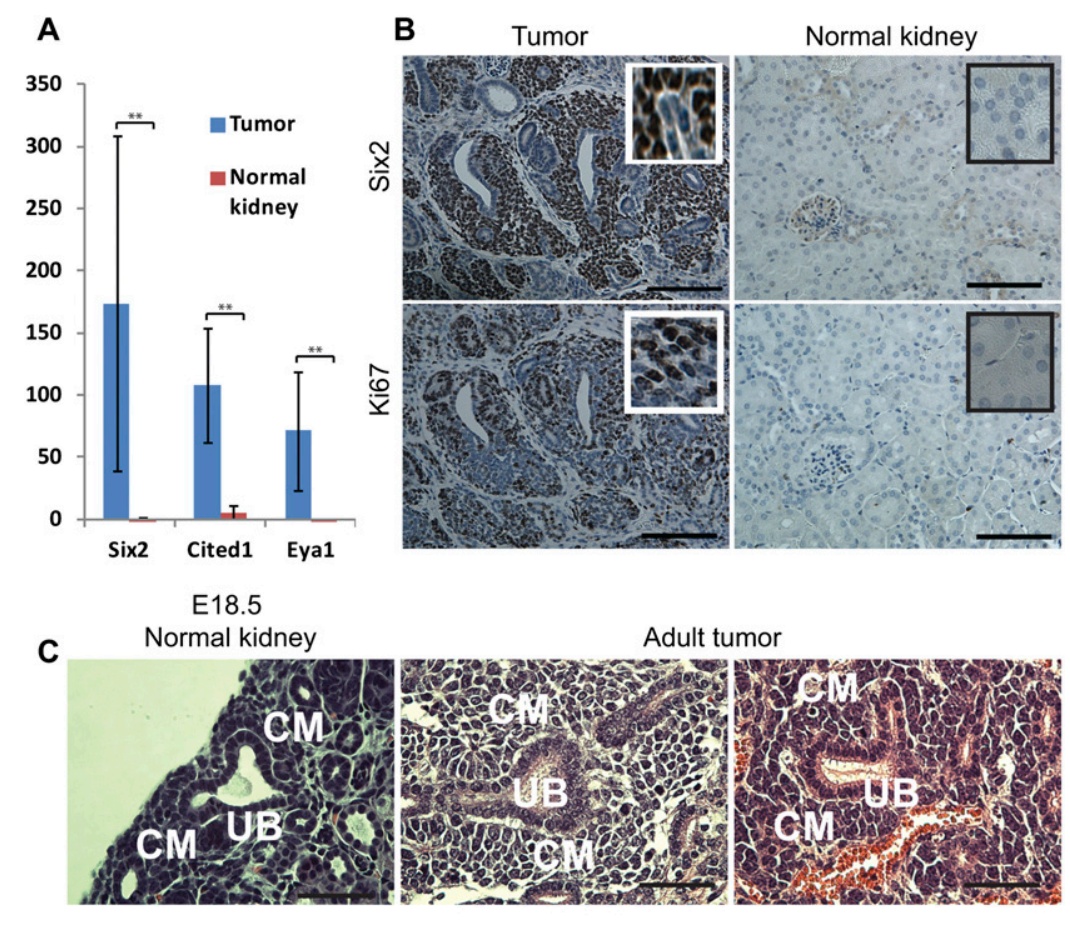

Figure 2. Lin28-derived tumors harbor proliferating CM cells. (A) Overexpression of CM-specific transcription factors in the tumor. Microarray data (tumor, $n=4$; control, $n=4$ ). (B) Six2 and Ki67 immunohistochemistry in normal kidneys and LIN28a-derived tumors. Bar, $100 \mu \mathrm{m}$. (C) Histology of the E18.5 nephrogenic zone and adult tumors. Note that embryonic structures consisting of a branched UB surrounded by CM cells appears in the adult tumors. Bar, $50 \mu \mathrm{m}$. $(D)$ Six2 and Keratin8 coimmunostaining in a normal embryonic kidney, a normal adult kidney, and an adult tumor. (Note: Keratin 8 is a marker for UB cells during kidney development and for the collecting duct in the adult kidney). In contrast to normal adult kidneys, in which Six2 is not expressed and keratin8 expression is restricted to the collecting duct, the expression pattern of Six2 and Keratin8 in the tumors is similar to the nephrogenic zone during kidney development. Bar, $100 \mu \mathrm{m}$.

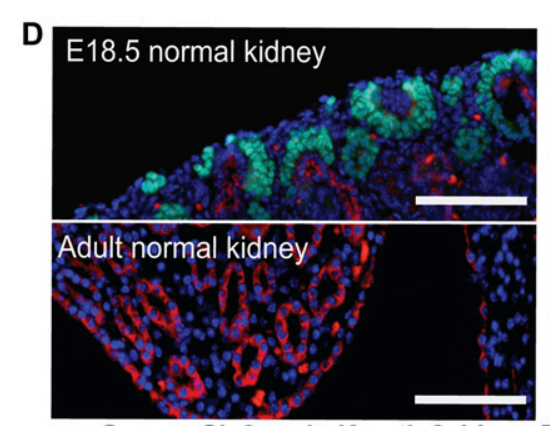

Green - Six2, red - Keratin8, blue - Dapi

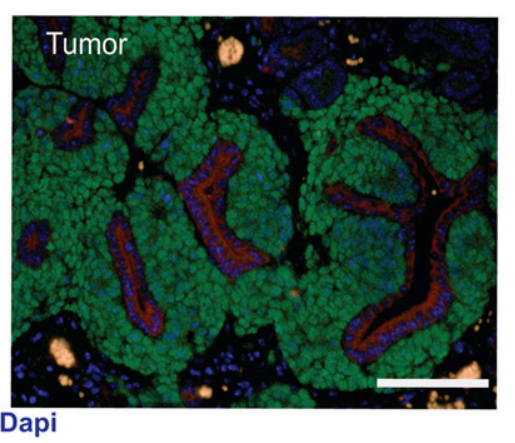

Lin28 prevents the postnatal wave of differentiation of the CM cells

We documented that Lin28 overexpression leads to persistent proliferation of CM cells in adult mice. During normal kidney development, Lin28 $a$ is expressed in CM cells until E13.5, after which expression wanes, while Lin28b is not expressed at all (Fig. 4A; Supplemental Fig. S4A). Interestingly, however, the nephrogenic zone of E18.5 transgenic embryos appears normal, without aberrant expansion of the CM cells (Fig. 4B; Supplemental Fig. $\mathrm{S} 4 \mathrm{~B})$, suggesting normal proliferation of the CM cells in the nephrogenic zone during embryonic development in the presence of Lin28. Importantly, induction of Lin28 overexpression as late as E18.5 was enough to sustain proliferation of CM cells into adulthood (Supplemental Fig. S4C). To discern whether ectopic Lin28 expression could reactivate proliferation of nephrogenic cells after the early postnatal period of terminal differentiation, we induced $L I N 28 B$ overexpression in renal tissues by virtue of gene activation via $W t 1$ Cre at P10, when no CM cells exist in the normal kidney. When $L I N 28 B$ was overexpressed at P10, tumors failed to develop, and expansion of Six2-positive cells was not detected (Supplemental Fig. S4D). Instead, late $L I N 28 B$ induction resulted in a cystic kidney phenotype (Supplemental Fig. S4E). Collectively, these data suggest that the CM cells retain their differentiation capacity in the presence of Lin28 expression but that Lin28 delays the timing of the final postnatal wave of synchronous differentiation, allowing the nephrogenic process to persist, eventually producing Wilms tumor.

Wilms tumor arises when Lin28 is overexpressed in multiple early kidney lineages

We then sought to determine in which cells of the developing kidney overexpression of Lin28 was required to promote Wilms tumor formation. We overexpressed $L I N 28 B$ or Lin28a specifically in CM cells by crossing Lox-tetOn-LIN28B and Lox-TetOn-Lin28a transgenic mice with Six2-Cre mice (Kobayashi et al. 2008). Contrary to expectation, overexpression of Lin28a or LIN28B in the CM cells failed to induce tumor forma- 


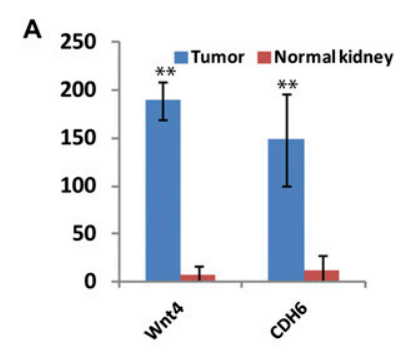

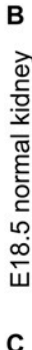
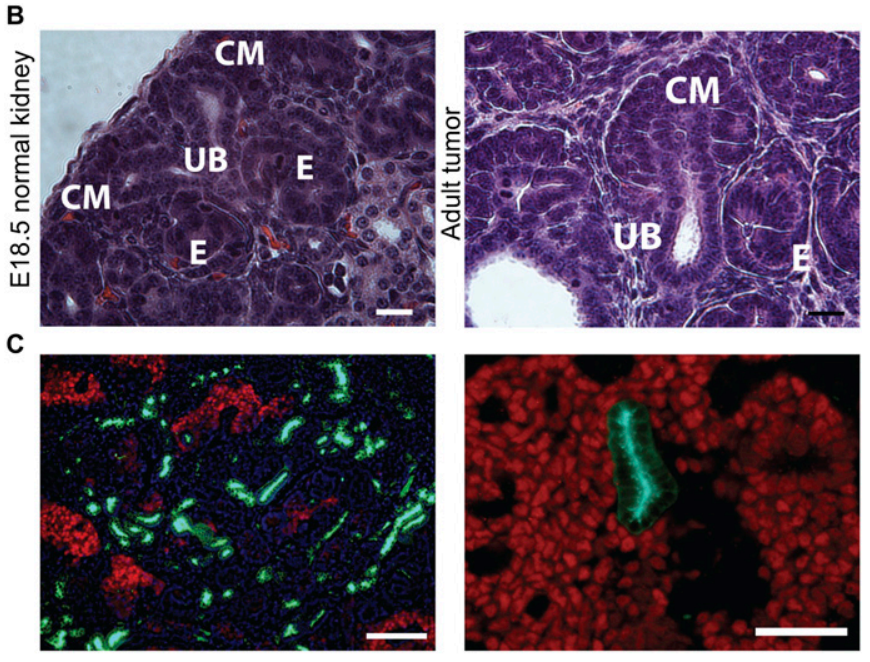

Green - LTL, red - Six2, blue - Dapi

Figure 3. Differentiation capacity of the CM cells in the tumor. (A) Overexpression of epithelialization markers Wnt4 and Cdh16 in the tumor. Microarray data (tumor, $n=4$; normal kidney, $n=4)$. (B) Epithelial structures in a normal embryonic kidney and a Lin28derived tumor. (E) Epithelial structures of comma-shaped/S-shaped bodies differentiated from the CM cells. Bar, $20 \mu \mathrm{m}$. (C) Mixture of progenitor cells (Six2-positive) and mature proximal tubule cells (LTL-positive) in the tumor. Bar, $100 \mu \mathrm{m}$.

tion (zero out of 15) but instead produced a cystic kidney phenotype. The cystic phenotype appeared in the Six2Cre-Lin28 mice when Lin28 overexpression was induced early in embryonic development (Supplemental Figs. S5A,B) or in adult mice (Supplemental Fig. S5C). We crossed Lox-TetOn-Lin28a/LIN28B mice with mice carrying FoxD1Cre $(n=10)$ to effect stromal cell-specific expression (Humphreys et al. 2010) and with mice carrying Cdh16Cre $(n=7)$ to effect UB cell-specific expression (Shao et al. 2002), but neither of these crossings reproduced the tumor phenotype. Interestingly, however, overexpression of LIN28B in stromal cells (FoxD1Cre) led to hydronephrosis in the adult kidney (Supplemental Fig. S5D), while no pathology was seen in the Cdh16Cre mice. Therefore, in the murine model, Lin28 activation is required in the earliest renal progenitor that gives rise to the multiple cell types of the developing kidney, implying that Lin28 promotes a coordinated prolongation of nephrogenesis, which ultimately progresses to Wilms tumor formation (see Fig. 1E).

Lin28 expression is required for the maintenance of CM cells within the tumor

Our data firmly establish a role for Lin28 overexpression in tumor initiation, but to determine whether continued
A

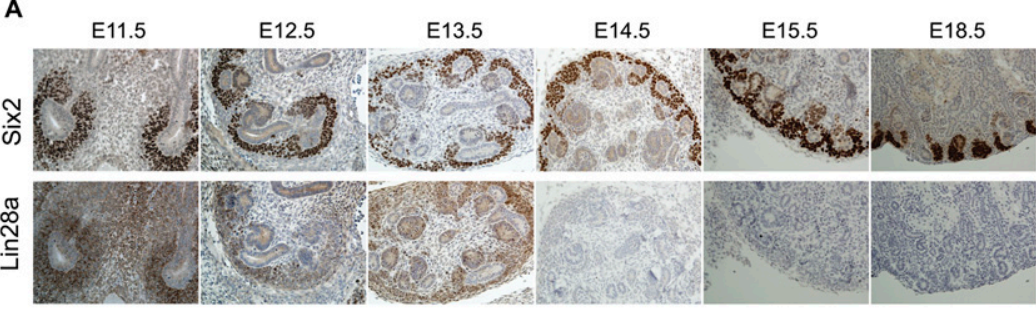

B

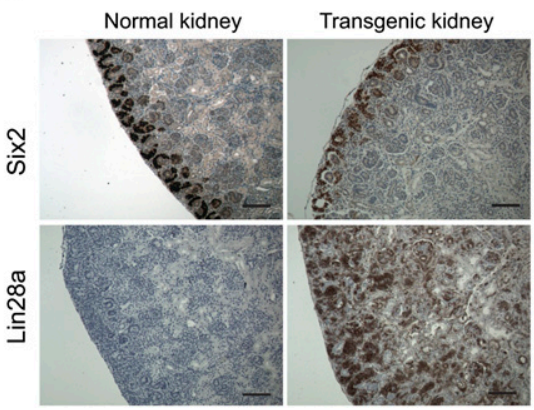

Figure 4. Lin28 overexpression prevents the postnatal wave of differentiation of the CM cells. $(A)$ Analysis of Lin28a expression during mouse embryonic kidney development. Lin28a is expressed in the CM (Six2-positive) cells of the developing kidney until E13.5. All panels are at the same scale. (B, top panel) Six2 expression in E18.5 normal and transgenic kidneys. (Bottom panels) Lin28a expression in normal and transgenic kidneys. Note that there is no expansion in CM cells of the transgenic kidney compared with the control. Bar, $100 \mu \mathrm{m}$. 
Urbach et al.

Lin28 expression is necessary for tumor maintenance, we studied the effect of Lin28 down-regulation by withdrawal of Dox commencing at P7. While significant numbers of Six2/Eya1-positive CM cells persist 2 wk after Dox withdrawal (Fig. 5A; Supplemental Fig $\mathrm{S} 6)$, at $3 \mathrm{wk}$ after Dox withdrawal, there was a signifi- cant decrease in CM cells in the kidneys of the transgenic mice, and not overt tumors, but a markedly increased number of well differentiated glomerulus-like structures (Fig. 5B,C). Thus, we conclude that expression of Lin28 is sufficient for tumor initiation and necessary for tumor maintenance.

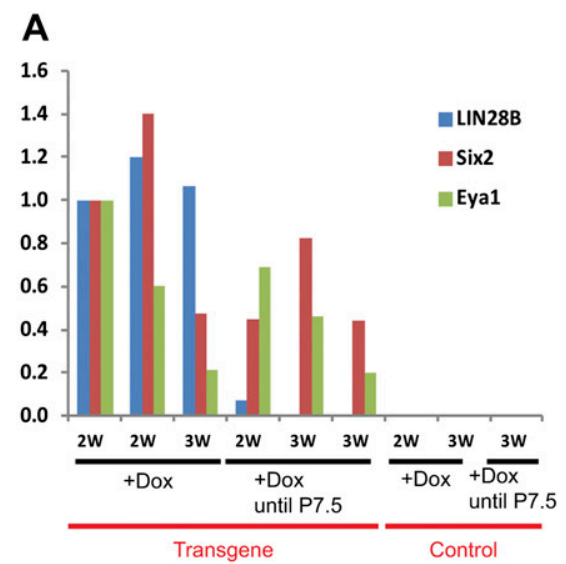

C
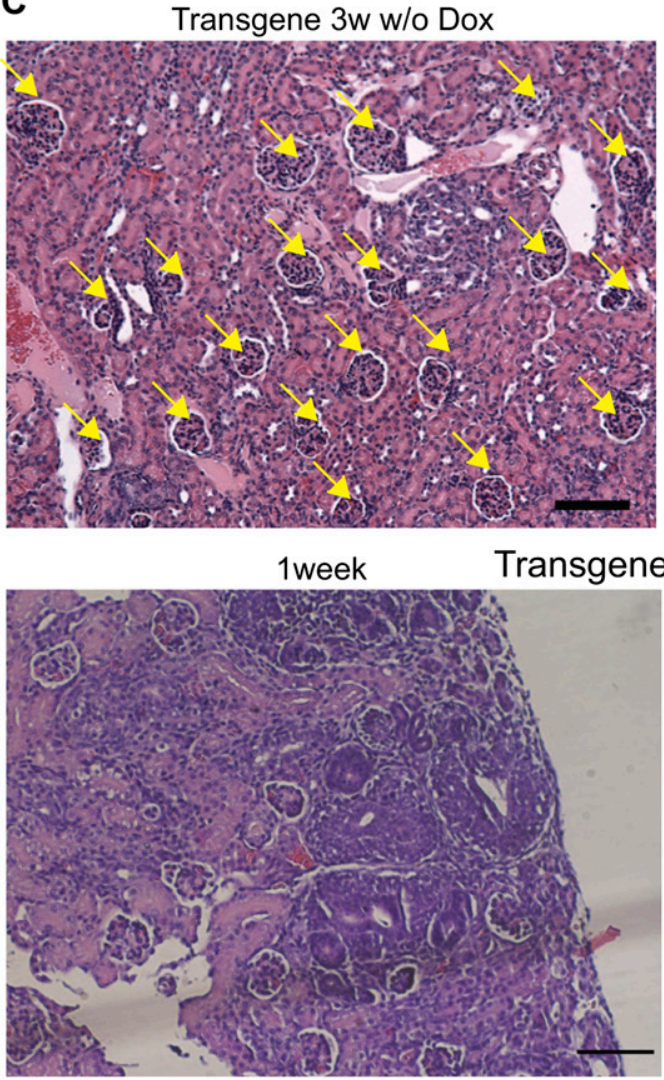
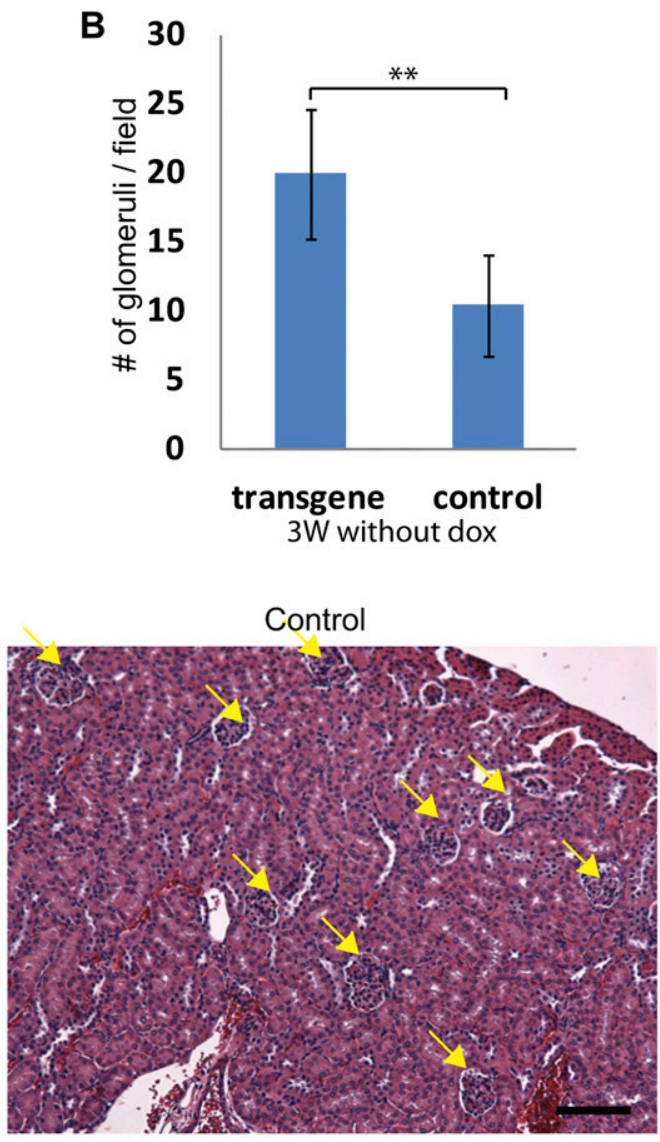

with Dox 4 weeks

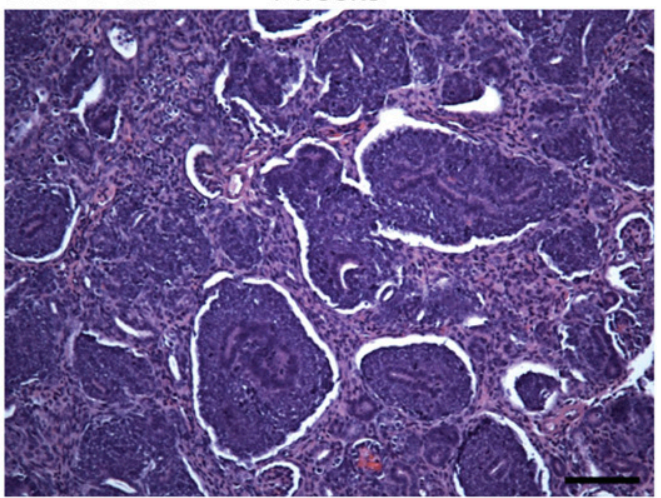

Figure 5. Lin28 down-regulation leads to differentiation of the CM cells in the tumor. (A) qRT-PCR analysis of LIN28B, Six2, and Eya1 (markers form CM cells) in transgenic and control kidneys 1 and $2 \mathrm{wk}$ after Dox withdrawal. (2W) 2-wk-old mice (1 wk without Dox); (3W) 3-wk-old mice (2 wk without Dox). Note that Six2 and Eya1 are still expressed 2 wk after Dox is withdrawn. (B) Average glomerulus number per $10 \times$ magnification field in the microscope in transgenic and control kidneys 3 wk after Dox withdrawal $(n=12)$. (C) Representative H\&E staining of transgenic kidneys 3 wk after Dox withdrawal (transgene 3 wk w/o Dox) compared with a control 4-wkold kidney and transgenic 1-wk-old and 4-wk-old kidneys maintained on Dox (transgene with Dox). Dox was induced from E0. Note that 3 wk after Dox withdrawal, the transgenic kidneys contain many glumerulus-like structures and do not contain CM cells. Yellow arrows point to glomerulus-like structures. Bar, $100 \mu \mathrm{m}$. 
Lin28-induced Wilms tumor is suppressed by enforced expression of Let-7

Analysis of miRNA expression in Lin28-induced tumors demonstrated significant suppression of mature Let-7 species (Supplemental Fig. S7A) but no significant change in steady-state levels of pri/pre-Let7 (Supplemental Fig. S7B). In accordance with this, Let7 target genes were upregulated in the tumors compared with control kidneys (Supplemental Fig S7C). To determine whether Lin28induced tumorigenesis could be suppressed by enforced restoration of Let-7, we crossed the tumor-prone LIN28B transgenic mice with a strain that expresses a chimeric Let-7g (i7s) species whose processing is not inhibited by Lin28 (Piskounova et al. 2008). We verified by immunohistochemistry staining that the transgenic kidneys overexpressed LIN28B (Supplemental Fig. S7D), that endogenous Let-7 was down-regulated when the chimeric Let- $7 g$ transgene was overexpressed in the LIN28B-i7s kidneys (Fig. 6A), and that Let-7 targets were down-regulated in the Lin28B;i7s kidneys compared with Lin28B kidneys (Supplemental Fig. S7E). We showed previously that the "i $7 \mathrm{~s}$ " mice are smaller than their littermate controls (Zhu
A

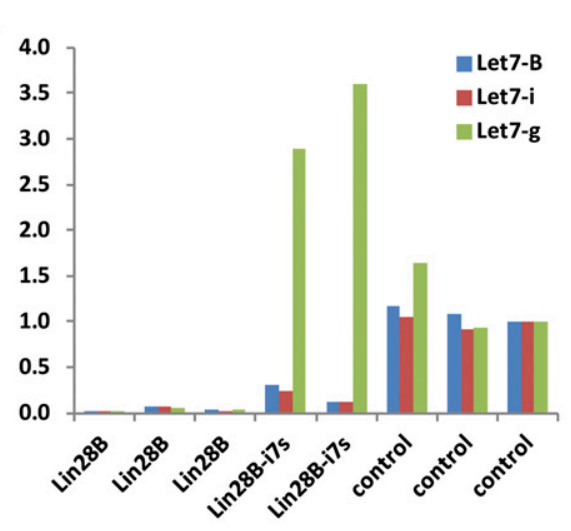

B
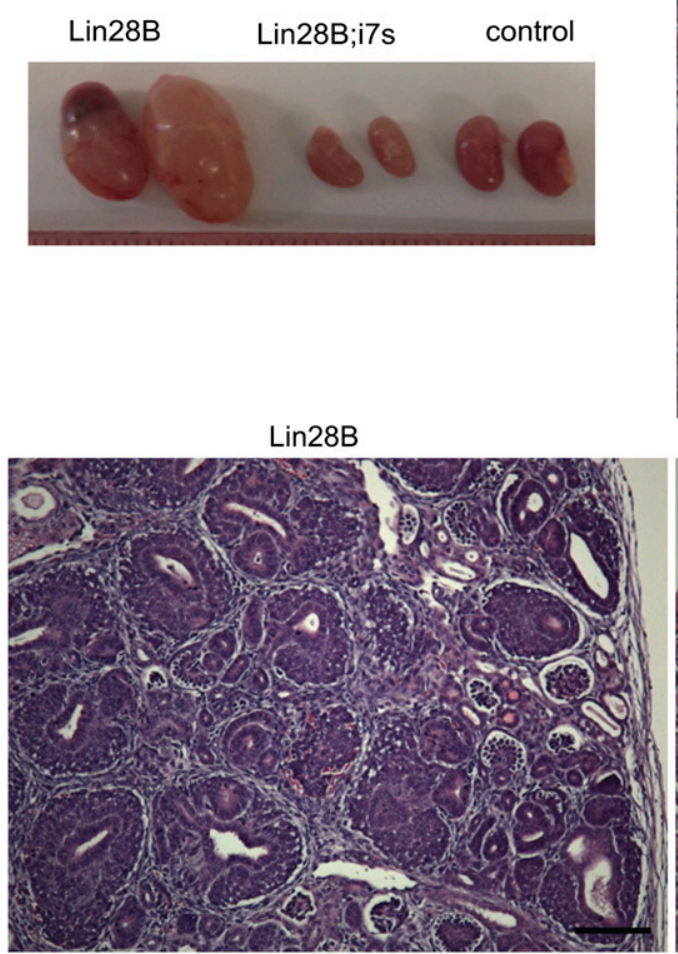

D
C
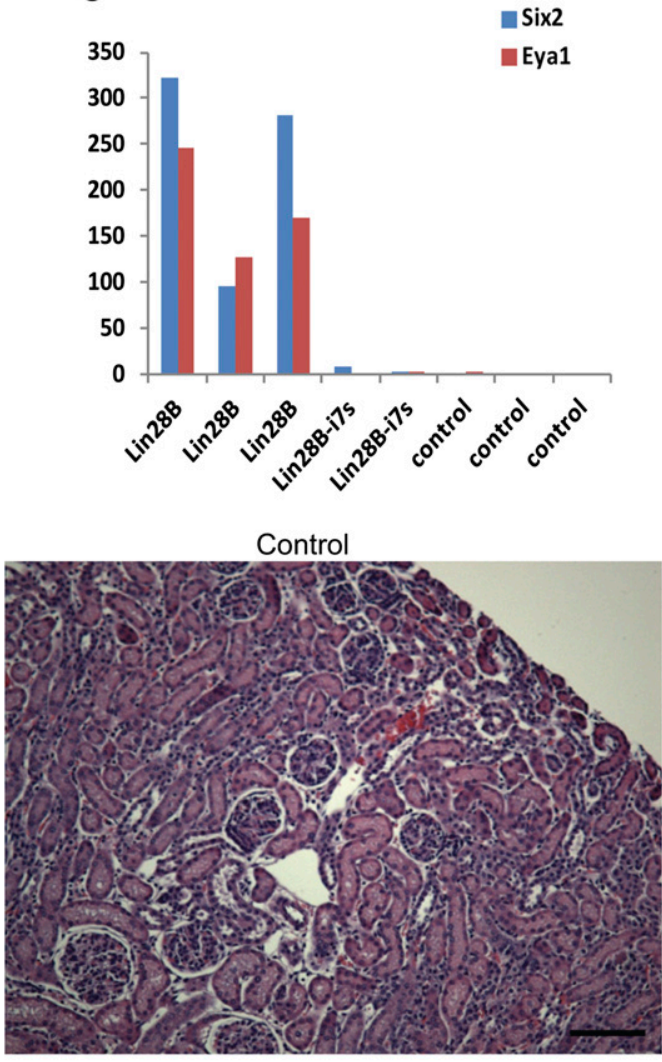

Lin28B-i7s

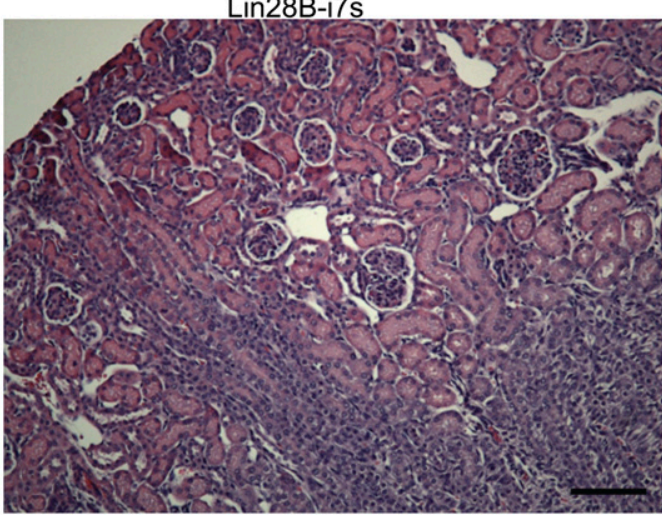

Figure 6. Lin28 acts thorough the Let7 pathway to prevent normal kidney development. (A) qRT-PCR analysis of mature Let7 levels in LIN28B, LIN28B;i7s, and control kidneys. Dox was provided from E14.5 until the end of the experiment. (B) Morphology of LIN28B, LIN28B;i7s, and control kidneys. (C) qRT-PCR analysis of the CM markers Six2 and Eya1 in LIN28B, LIN28B;i7s, and control kidneys. (D) H\&E staining of LIN28B, LIN28B;i7s, and control kidneys. Note that the Lin28B;i7s kidneys have a normal histology. Bar, $100 \mu \mathrm{m}$. 
et al. 2011). Accordingly, kidneys of compound LIN28Bi7s mice appeared smaller than normal kidneys (Fig. 6B). Importantly, however, there were no evidence of persistent CM cells in the LIN28B-i7s kidneys, as demonstrated by quantitative RT-PCR (qRT-PCR) (Fig. 6C) and histology (Fig. 6D). These results demonstrate that enforced Let-7 expression can counteract the effect of $L I N 28 B$ overexpression, suggesting that $L I N 28 B$ induces Wilms tumor at least in part by suppressing Let-7 miRNAs.

\section{LIN28B expression in human Wilms tumor}

Cancer-initiating cells (CICs) have recently been isolated from human Wilms tumor (Pode-Shakked et al. 2013). We detected overexpression of LIN28B (but not LIN28A) in $\mathrm{NCAM}^{+} \mathrm{ALDH}^{+}$wild-type CICs isolated from earlygeneration Wilms tumor xenografts (harboring a blastemal predominant phenotype) and to a lesser extent in primary Wilms tumor when compared with developing human kidneys (Supplemental Fig. S8A). To determine whether LIN28 expression is a prominent feature of human Wilms tumor, we analyzed the expression of LIN28A and LIN28B in human Wilms tumor samples from Boston Children's Hospital (USA, $n=28$ ) and an independent set from Great Ormond Street Hospital/University College London Institute of Child Health (UK, $n=77$ ). Indeed, immunohistochemical staining of these samples revealed overexpression of LIN28B (Fig. 7A) in eight out of 28 and 10 out of 77 samples, respectively, compared with normal kidneys. Conversely, LIN28A expression was not detected in any sample. This observation was further supported by our analysis of published microarray data that indicated frequent expression of LIN28B but not LIN28A in human Wilms tumor (Fig. 7B; Supplemental Fig. S8B).

In our tissue microarray analyses (UK samples), we noted that LIN28B expression was restricted to blastemal cells, which are the most undifferentiated tumor component. Clinical outcome data were available for 76 out of 77 UK patients who had been uniformly treated with prenephrectomy chemotherapy. Among the nine LIN28Bpositive tumors, five patients relapsed, and three died. Among the 67 LIN28B-negative tumors, eight patients relapsed, and two died, thus suggesting a significant association of LIN28B expression with relapse and death $(P=$ 0.0059 and $P=0.0105$, respectively, two-tailed Fisher's test). Detailed histological and statistical analysis of the LIN28B-positive and LIN28B-negative tumors can be found in Supplemental Tables 1 and 2. Taken together, these data indicate that expression of LIN28B is a feature of a significant minority of cases of human Wilms tumor, which, together with our prior report of activation of LIN28B by chromosomal translocation in two cases, implicates LIN28 in the pathogenesis of human Wilms tumor.

\section{Discussion}

It has been argued that pediatric cancer can arise from the failure of embryonic cells to complete their differentiation program (Maris and Denny 2002; Messahel et al. 2005), indicating that the pathogenesis of pediatric tumors is
A

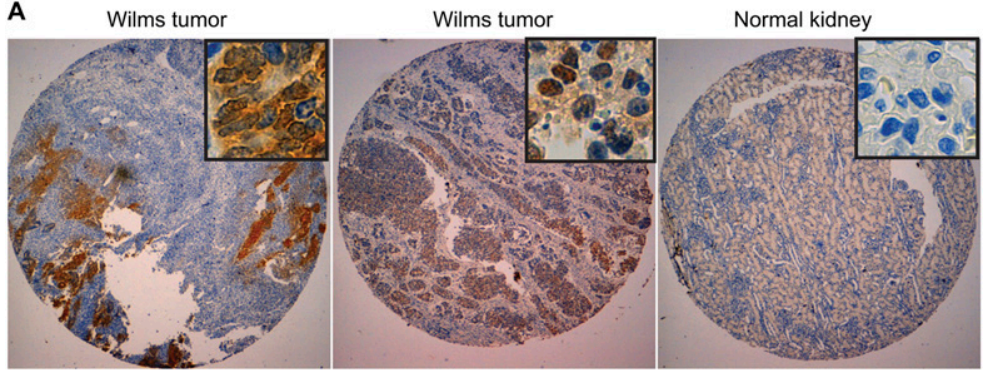

B

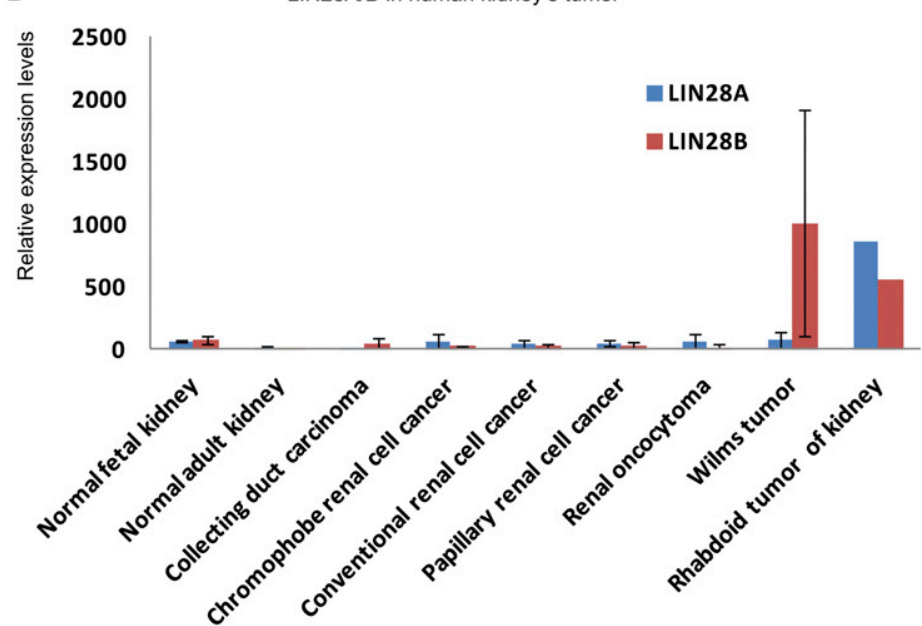

Figure 7. LIN28B expression in human Wilms tumor. (A) LIN28B immunohistochemistry in human Wilms tumor. (B) LIN28B and LIN28A expression levels in diverse types of human renal tumors based on published microarray data (GSE11151). 
directly linked to dysregulated embryonic development and organogenesis (Scotting et al. 2005). Here we demonstrate that overexpression of Lin28, an RNA-binding protein linked to pluripotency, stem cell self-renewal, and delayed larval development in C. elegans, prolongs kidney development and promotes Wilms tumor formation. Reminiscent of its association with heterochronic phenotypes in C. elegans, Lin28 overexpression prevents the synchronous wave of differentiation of CM cells in the developing kidney, which, under normal conditions, is complete by $\mathrm{P} 2$ in mice (Hartman et al. 2007) and by 36 wk of gestation in humans (Hinchliffe et al. 1991). In transgenic mice engineered for kidney-specific Lin28 overexpression, CM cells continue to proliferate into adulthood, resulting in conversion to a tumor highly reminiscent of human Wilms tumor. When activation of Lin28 was targeted to specific cellular compartments such as UB, stroma, or CM cells, we failed to observe tumor formation; instead, in our model, Cre excision in the intermediate mesoderm, the origin of the entire kidney, was required to induce tumor formation. Theoretically, this observation suggests that Lin28 activation is required in either a stage-specific manner in the earliest kidney progenitor cells or more than one kidney cell lineage. The fact that tumors formed when Lin28 overexpression was induced as late as E18.5, when the earliest progenitors no longer exist, suggests that the second explanation is more likely. Our model implies that aberrant Lin28 expression produces a coordinated expansion of the nephrogenic zone, resulting in proliferating blastema and nephrogenic rests, which are characteristic of human Wilms tumor.

Previously, a murine model of Wilms tumor was generated by Wt1 ablation and Igf2 overexpression (Hu et al. 2011), which established that Wt1 ablation prevents the MET of CM cells that is essential for nephrogenesis. In contrast, in our model, the CM cells persist beyond the period when synchronous differentiation typically occurs and retain their capacity to undergo MET, resulting in a markedly expanded period of nephrogenesis that ultimately progresses to frank tumorigenesis. The differences between these two models demonstrate that pediatric Wilms tumor formation can occur at diverse stages of development and through different molecular mechanisms.

Lin28 has profound effects on both the proliferative and metabolic machinery of tumor cells. By virtue of blocking Let-7 biogenesis, Lin28 leads to derepression of known oncogenic targets of Let-7 such as Myc (Sampson et al. 2007), Ras (Johnson et al. 2005), Hmga2 (Lee and Dutta 2007; Mayr et al. 2007), and cyclins (Legesse-Miller et al. 2009; Chang et al. 2012). Moreover, Lin28 has been shown to promote glycolytic metabolism in tissues and cancer cells and thus is a central regulator of cellular bioenergetics (Shyh-Chang et al. 2013). It appears that Lin28 functions to balance the proliferative and metabolic needs of rapidly growing cells in the early embryo (Shinoda et al. 2013b) and that this function becomes reactivated in many adult tumors. In cases of pediatric malignancy, Lin28 appears to prolong the embryonic patterns of tissue growth (as we showed here for Wilms tumor), which is likely the case for germ cell tumors and neuroblastoma.
Point mutations in $W T 1, W T X, \beta$-catenin, and abnormalities involving translocations in chromosome 6 have been linked to Wilms tumor (Knudson and Strong 1972; Rivera and Haber 2005; Hu et al. 2011), and several susceptibility loci for Wilms tumor were recently identified by a genome-wide association study (Turnbull et al. 2012). However, the underlying genetic basis of most cases of Wilms tumor remains unknown (Turnbull et al. 2012). Here we report that up to a third of human Wilms tumors overexpress LIN28B. Moreover, our data suggest an association of LIN28B expression with a "high-risk" subtype of Wilms tumor called "blastemal type" (Vujanic et al. 2002) that is defined by the persistence of a large proportion of blastemal cells in the viable tumor component after prenephrectomy chemotherapy. Therefore, LIN28B expression may be a marker of such therapyresistant blastemal cells, which currently cannot be identified in chemo-naïve tumors treated according to the North American approach of immediate nephrectomy, but a much larger unselected cohort of tumors would be required to investigate this properly. Prior studies have implicated aberrant expression of the HACE1 locus on chromosome 6 in Wilms tumor (Slade et al. 2010), but LIN28B is tightly linked to this locus, and our detection of aberrant overexpression of LIN28B in a significant minority of human Wilms tumors suggests the possibility of coordinate dysregulation. Previously, we reported that rare cases of Wilms tumor result from activation of $L I N 28 B$ by chromosomal translocation and that amplification of the LIN28B locus occurs in only $\sim 2 \%$ of tumors (Viswanathan et al. 2009); thus, the mechanism of LIN28B activation remains unexplained in most cases. Based on our demonstration that both murine Lin28 a and human LIN28B are competent to induce Wilms tumor in our mouse model, we speculate that the prevalence of $L I N 28 B$ activation and the absence of aberrant LIN28A expression in human Wilms tumor is likely due to a specific mechanism of LIN28B up-regulation and not differences in the transforming potential of the genes. In support of this hypothesis, it has been shown recently (Aiden et al. 2010) that the promoter of LIN28A in human Wilms tumors is enriched with histone K27me3.

The miRNA pathway is a common target for dysregulation in different types of tumors (Merritt et al. 2008; Bahubeshi et al. 2011). Recently, it was demonstrated that DIS3L2, the gene responsible for Perlman syndrome, which entails a predisposition to Wilms tumor, is a nuclease responsible for degrading Let-7 miRNAs that have become polyuridylated due to Lin28-mediated recruitment of a terminal uridylyl transferase (Chang et al. 2013). Taken together with the observation of LIN28B overexpression in up to $30 \%$ of human Wilms tumors and our demonstration that enforced expression of Let-7 abrogates Lin28-induced kidney tumorigenesis, these data suggest that a common mechanism of Wilms tumor pathophysiology is dysregulation of LET-7 miRNA biogenesis or function. This hypothesis would be reinforced if indeed Drosha and Dicerl mutations or other mutation in the miRNA processing machinery are likewise found in Wilms tumor. The LIN28/ LET-7 pathway represents an appealing therapeutic target 
for Wilms tumor through either inhibition of LIN28 function or delivery of LET-7 to tumor cells.

\section{Materials and methods}

Mice

All animal procedures were conducted according to animal care guidelines approved by the Institutional Animal Care and Use Committee at Boston Children's Hospital.

\section{LSL-Lin28 a mice}

A Lox-stop (four PGK-polyA and three sv40 polyA) Lox cassette and a Flag-tagged murine Lin28a ORF were cloned into pEF6 plasmid (Invitrogen, catalog no. V962-20) downstream from a PEF- $1 \alpha$ promoter, and targeting was performed into V6.5 embryonic stem cells. Chimeric mice were generated by injection of embryonic stem cells into BALB/c blastocysts and then bred to CD-1 females to generate germline-transmitted pups.

Lox-TetOn-Lin28 mice were previously generated in our laboratory as described in Zhu et al. $(2010,2011)$.

The following Cre mice were obtained from Jackson laboratory: VasaCre (stock no. 006954), Six2Cre (stock no. 009606), FoxD1Cre (stock no. 012463), and Cdh16Cre (stock no. 012237). The Wt1Cre mice were contributed by the laboratory of Dr. William Pu at Boston Children's Hospital. Cre mice were crossed to the Lox-TetOn-Lin 28 mice, and $1 \mathrm{mg} / \mathrm{mL}$ Dox was administered to the drinking water at different time points to induce $L I N 28 B / L i n 28 a$ expression. To achieve co-overexpression of Lin28 and Let7, we crossed Wt1Cre mice with TRE-7S21L ("i7s" mice) mice and then crossed the Wt1Cre;i7s mice with Lox-TetOn-Lin28 mice.

For the transplantation experiments, embryos were harvested by cesarean section at E18.5. Kidneys were harvested from transgenic and control embryos, dissected to smaller pieces, and then transplanted under the kidney capsules of NSG mice.

\section{$q R T-P C R$}

RNA was isolated by TRIzol and reverse-transcribed using SuperScript III (Invitrogen, catalog no. 18080-051) or miScript II RT kit (Qiagen, catalog no. 218161). mRNA expression was measured by qPCR using the $\Delta \Delta \mathrm{CT}$ method with the following primers: mLin28a: $\mathrm{mSix} 2$ (forward primer, GCAAGTCAGCA ACTGGTTCA; reverse primer, CTTCTCATCCTCGGAACT GC), mEya1 (forward primer, TTTCCCTGGGACTACGAATG; reverse primer, GGAAAGCCATCTGTTCCAAA), mGapdh (forward primer, GCAGTGGCAAAGTGGAGATTG; reverse primer, AATTTGCCGTGAGTGGAGTCATC), and mbActin (forward primer, TACTCCTGCTTGCTGATCCAC; reverse primer, CA GAAGGAGATTACTGCTCTGGCT); and hLIN28B (forward primer, GCCCCTTGGATATTCCAGTC; reverse primer, TGACT CAAGGCCTTTGGAAG). For qRT-PCR of mature Let7 miRNA and pre/pri-Let7, we used Qiagen miScript target as described in the miScript protocol.

\section{Microarray}

RNA from four Lin28a-derived Wilms tumor samples and four control kidneys was harvested and processed using TRIzol. The Illumina Ref-8 microarray platform was used by the Boston Children's Hospital Intellectual and Developmental Disabilities Research Center (IDDRC) Molecular Genetics Core Facility. The microarray data have been deposited in Gene Expression Omnibus
(GEO) and given the series accession number GSE56323. Gene set enrichment analysis (GSEA) was used to identify gene sets and pathways associated with a set of up-regulated or down-regulated genes. Published microarray data from GEO (GSE3822, GSE6890, and GSE12588) were used for the analysis of Lin28a and Lin28b during mouse kidney development. Data from Oncomine (https:// www.oncomine.org) were used for the analysis of LIN28A and LIN28B expression in human Wilms tumor samples.

\section{Histological analysis}

Tissue samples were fixed in $10 \%$ buffered formalin and embedded in paraffin. Immunostaining was performed using the following antibodies: LIN28A (1:250; Cell Signaling, catalog no. 8641S), LIN28B (1:250; Cell Signaling, catalog no. 4196S), SIX2 (1:400; Proteintech Group, catalog no. 11562-1-AP), LTL (1:500; Vector Laboratories, catalog no. FL-1321), and Keratin 8 (1:50; Developmental Studies Hybridoma Bank [DSHB], catalog no. TROMA-I-s [TROMA-I-s]).

Slides were dewaxed with xylene and rehydrated through a series of washes with decreasing percentages of ethanol. Antigen retrieval was performed in $10 \mathrm{mM}$ sodium citrate buffer $(\mathrm{pH}$ 6.0) by placement in a decloaking chamber for $30 \mathrm{~min}$ on high temperature.

Immunohistochemistry was performed with Elite ABC kit and $\mathrm{DAB}$ substrate (Vector Laboratories) according to the manufacturer's protocol. For immunofluorescence, Alexa 488- or Alexa568-conjugated goat anti-rabbit or goat anti-mouse secondary antibodies were used. Lin28B immunohistochemistry was scored as positive versus absent staining. In all cases, positive staining was seen in groups of blastemal cells.

To compare the nephron number between transgenic mice and controls, we count the number of glomerulus-like structures in 12 random fields (from the kidney cortex) under 10× magnification.

\section{Statistical analysis}

Data are presented as mean \pm SEM, and Student's $t$-test (twotailed distribution, two-sample unequal variance) was used to calculate $P$-values. Statistical significance is displayed as $P<$ $0.05\left(^{\star}\right)$ or $P<0.01\left(^{\star \star}\right)$ unless specified otherwise. The tests were performed using Microsoft Excel, with the test type always set to two-sample equal variance.

\section{Acknowledgments}

We thank all of the clinicians at Boston Children's Hospital and the UK Children's Cancer and Leukaemia Group (CCLG) Centres who managed the care of the children entered into clinical and biology studies. We especially thank Dr. Richard Williams and Mr. Tasnim Chagtai (University College London [UCL] Institute of Child Health) for access to clinical and microarray expression data, and Dr. Sergey Popov (Institute of Cancer Research, University of London) and Professor Gordan Vujanic (University of Wales Medical School, Cardiff University) for assistance with construction of TMAs from patients treated in the SIOP WT 2001 trial in the UK. We thank the CCLG Tissue Bank for access to samples. G.Q.D. is an investigator of the Howard Hughes Medical Institute and the Manton Center for Orphan Disease Research and an affiliate member of the Broad Institute. This work was funded by the Ellison Medical Foundation and private funds of the Children's Hospital. K.P.-J. receives support from Cancer Research UK, Great Ormond Street Children's Charity, Children with Cancer Charity, and the National Institute for Health Research, Great Ormond Street Hospital, UCL Biomedical Research Centre award. The CCLG Tissue Bank is funded by Cancer Research UK and CCLG. 


\section{References}

Aiden AP, Rivera MN, Rheinbay E, Ku M, Coffman EJ, Truong TT, Vargas SO, Lander ES, Haber DA, Bernstein BE. 2010. Wilms tumor chromatin profiles highlight stem cell properties and a renal developmental network. Cell Stem Cell 6: 591-602.

Ambros V, Horvitz HR. 1984. Heterochronic mutants of the nematode Caenorhabditis elegans. Science 226: 409-416.

Bahubeshi A, Tischkowitz M, Foulkes WD. 2011. miRNA processing and human cancer: DICER1 cuts the mustard. Sci Transl Med 3: $111 \mathrm{ps} 146$.

Chang HM, Martinez NJ, Thornton JE, Hagan JP, Nguyen KD, Gregory RI. 2012. Trim71 cooperates with microRNAs to repress Cdknla expression and promote embryonic stem cell proliferation. Nature Commun 3: 923.

Chang HM, Triboulet R, Thornton JE, Gregory RI. 2013. A role for the Perlman syndrome exonuclease Dis312 in the Lin28let-7 pathway. Nature 497: 244-248.

Davidson AJ. 2009. Mouse kidney development. In StemBook, (ed. The Stem Cell Research Community), doi: 10.3824/ stembook.1.34.1, http://www.stembook.org.

Diskin S, Capasso M, Schnepp R, Cole K, Attiyeh E, Hou C, Diamond M, Carpenter E, Winter C, Lee H, et al. 2012. Common variation at 6q16 within HACE1 and LIN28B influences susceptibility to neuroblastoma. Nat Genet 445: 1126-1130.

Gallardo T, Shirley L, John GB, Castrillon DH. 2007. Generation of a germ cell-specific mouse transgenic Cre line, Vasa-Cre. Genesis 45: 413-417.

Gillis AJ, Stoop H, Biermann K, van Gurp RJ, Swartzman E, Cribbes S, Ferlinz A, Shannon M, Oosterhuis JW, Looijenga LH. 2011. Expression and interdependencies of pluripotency factors LIN28, OCT3/4, NANOG and SOX2 in human testicular germ cells and tumours of the testis. Int I Androl 34: e160-e174.

Grobstein C. 1955. Inductive interaction in the development of the mouse metanephros. J Exp Zool 130: 319-339.

Grobstein C. 1956. Trans-filter induction of tubules in mouse metanephrogenic mesenchyme. Exp Cell Res 10: 424-440.

Hartman HA, Lai HL, Patterson LT. 2007. Cessation of renal morphogenesis in mice. Dev Biol 310: 379-387.

Hatini V, Huh SO, Herzlinger D, Soares VC, Lai E. 1996. Essential role of stromal mesenchyme in kidney morphogenesis revealed by targeted disruption of Winged Helix transcription factor BF-2. Genes Dev 10: 1467-1478.

Heo I, Joo C, Cho J, Ha M, Han J, Kim VN. 2008. Lin28 mediates the terminal uridylation of let-7 precursor microRNA. Mol Cell 32: 276-284.

Hinchliffe SA, Sargent PH, Howard CV, Chan YF, van Velzen D. 1991. Human intrauterine renal growth expressed in absolute number of glomeruli assessed by the disector method and Cavalieri principle. Lab Invest 64: 777-784.

Hu Q, Gao F, Tian W, Ruteshouser E, Wang Y, Lazar A, Stewart J, Strong L, Behringer R, Huff V. 2011. Wt1 ablation and Igf2 upregulation in mice result in Wilms tumors with elevated ERK1/2 phosphorylation. J Clin Invest 121: 174-257.

Huff V. 2011. Wilms' tumours: about tumour suppressor genes, an oncogene and a chameleon gene. Nat Rev Cancer 11: 111132.

Humphreys BD, Lin SL, Kobayashi A, Hudson TE, Nowlin BT, Bonventre JV, Valerius MT, McMahon AP, Duffield JS. 2010. Fate tracing reveals the pericyte and not epithelial origin of myofibroblasts in kidney fibrosis. Am J Pathol 176: 85-97.

Johnson SM, Grosshans H, Shingara J, Byrom M, Jarvis R, Cheng A, Labourier E, Reinert KL, Brown D, Slack FJ. 2005.
RAS is regulated by the let-7 microRNA family. Cell 120: 635-647.

Knudson AG Jr, Strong LC. 1972. Mutation and cancer: a model for Wilms' tumor of the kidney. I Natl Cancer Inst 48: 313324.

Kobayashi A, Valerius M, Mugford J, Carroll T, Self M, Oliver G, McMahon A. 2008. Six2 defines and regulates a multipotent self-renewing nephron progenitor population throughout mammalian kidney development. Cell Stem Cell 3: 169-250.

Lee YS, Dutta A. 2007. The tumor suppressor microRNA let-7 represses the HMGA2 oncogene. Genes Dev 21: 1025-1030.

Legesse-Miller A, Elemento O, Pfau SJ, Forman JJ, Tavazoie S, Coller HA. 2009. let-7 Overexpression leads to an increased fraction of cells in G2/M, direct down-regulation of Cdc34, and stabilization of Weel kinase in primary fibroblasts. J Biol Chem 284: 6605-6609.

Maris JM. 2010. Recent advances in neuroblastoma. N Engl J Med 362: 2202-2211.

Maris JM, Denny CT. 2002. Focus on embryonal malignancies. Cancer Cell 2: 447-450.

Mayr C, Hemann MT, Bartel DP. 2007. Disrupting the pairing between let-7 and Hmga2 enhances oncogenic transformation. Science 315: 1576-1579.

Merritt WM, Lin YG, Han LY, Kamat AA, Spannuth WA, Schmandt R, Urbauer D, Pennacchio LA, Cheng JF, Nick AM, et al. 2008. Dicer, Drosha, and outcomes in patients with ovarian cancer. N Engl J Med 359: 2641-2650.

Messahel B, Hing S, Nash R, Jeffrey I, Pritchard-Jones K. 2005. Clinical features of molecular pathology of solid tumours in childhood. Lancet Oncol 6: 421-430.

Molenaar J, Domingo-Fernández R, Ebus M, Lindner S, Koster J, Drabek K, Mestdagh P, van Sluis P, Valentijn L, van Nes J, et al. 2012. LIN28B induces neuroblastoma and enhances MYCN levels via let-7 suppression. Nat Genet 44: 1199-1206.

Moss EG, Lee RC, Ambros V. 1997. The cold shock domain protein LIN-28 controls developmental timing in C. elegans and is regulated by the lin-4 RNA. Cell 88: 637-646.

Murray MJ, Saini HK, Siegler CA, Hanning JE, Barker EM, van Dongen S, Ward DM, Raby KL, Groves IJ, Scarpini CG, et al. 2013. LIN28 Expression in malignant germ cell tumors downregulates let-7 and increases oncogene levels. Cancer Res 73: 4872-4884.

Newman MA, Thomson JM, Hammond SM. 2008. Lin-28 interaction with the Let-7 precursor loop mediates regulated microRNA processing. RNA 14: 1539-1549.

Oosterhuis JW, Looijenga LH. 2005. Testicular germ-cell tumours in a broader perspective. Nat Rev Cancer 5: 210-222.

Piskounova E, Viswanathan SR, Janas M, LaPierre RJ, Daley GQ, Sliz P, Gregory RI. 2008. Determinants of microRNA processing inhibition by the developmentally regulated RNAbinding protein Lin28. J Biol Chem 283: 21310-21314.

Pleniceanu O, Harari-Steinberg O, Dekel B. 2010. Concise review: Kidney stem/progenitor cells: differentiate, sort out, or reprogram? Stem Cells 28: 1649-1709.

Pode-Shakked N, Shukrun R, Mark-Danieli M, Tsvetkov P, Bahar S, Pri-Chen S, Goldstein RS, Rom-Gross E, Mor Y, Fridman E et al. 2013. The isolation and characterization of renal cancer initiating cells from human Wilms' tumour xenografts unveils new therapeutic targets. $E M B O \mathrm{Mol} M e d$ 5: $18-37$.

Rivera M, Haber D. 2005. Wilms' tumour: connecting tumorigenesis and organ development in the kidney. Nat Rev Cancer 5: 699-712.

Rumballe B, Georgas K, Combes A, Ju A, Gilbert T, Little M. 2011. Nephron formation adopts a novel spatial topology at cessation of nephrogenesis. Dev Biol 360: 110-122. 
Urbach et al.

Rybak A, Fuchs H, Smirnova L, Brandt C, Pohl EE, Nitsch R, Wulczyn FG. 2008. A feedback loop comprising lin-28 and let-7 controls pre-let-7 maturation during neural stem-cell commitment. Nat Cell Biol 10: 987-993.

Sampson VB, Rong NH, Han J, Yang Q, Aris V, Soteropoulos P, Petrelli NJ, Dunn SP, Krueger LJ. 2007. MicroRNA let-7a down-regulates MYC and reverts MYC-induced growth in Burkitt lymphoma cells. Cancer Res 67: 9762-9770.

Scotting P, Walker D, Perilongo G. 2005. Childhood solid tumours: a developmental disorder. Nat Rev Cancer 5: $481-488$.

Shao X, Somlo S, Igarashi P. 2002. Epithelial-specific Cre/lox recombination in the developing kidney and genitourinary tract. I Am Soc Nephrol 13: 1837-1846.

Shinoda G, De Soysa TY, Seligson MT, Yabuuchi A, Fujiwara Y, Huang PY, Hagan JP, Gregory RI, Moss EG, Daley GQ. 2013a. Lin28a regulates germ cell pool size and fertility. Stem Cells 31: 1001-1009.

Shinoda G, Shyh-Chang N, Soysa TY, Zhu H, Seligson MT, Shah SP, Abo-Sido N, Yabuuchi A, Hagan JP, Gregory RI, et al. 2013b. Fetal deficiency of lin28 programs life-long aberrations in growth and glucose metabolism. Stem Cells 31: 1563-1573.

Shyh-Chang N, Daley G. 2013. Lin28: primal regulator of growth and metabolism in stem cells. Cell Stem Cell 12: 395-406.

Shyh-Chang N, Zhu H, Yvanka de Soysa T, Shinoda G, Seligson MT, Tsanov KM, Nguyen L, Asara JM, Cantley LC, Daley GQ. 2013. Lin28 enhances tissue repair by reprogramming cellular metabolism. Cell 155: 778-792.

Slade I, Stephens P, Douglas I, Barker K, Stebbings L, Abbaszadeh F, Pritchard-Jones K, Cole R, Pizer B, Stiller C, et al. 2010. Constitutional translocation breakpoint mapping by genome-wide paired-end sequencing identifies HACE1 as a putative Wilms tumour susceptibility gene. I Med Genet 47: 342-347.

Turnbull C, Perdeaux ER, Pernet D, Naranjo A, Renwick A, Seal S, Munoz-Xicola RM, Hanks S, Slade I, Zachariou A, et al. 2012. A genome-wide association study identifies susceptibility loci for Wilms tumor. Nat Genet 44: 681-684.

Viswanathan SR, Daley GQ. 2010. Lin28: a microRNA regulator with a macro role. Cell 140: 445-449.

Viswanathan SR, Daley GQ, Gregory RI. 2008. Selective blockade of microRNA processing by Lin28. Science 320: 97-100.

Viswanathan SR, Powers JT, Einhorn W, Hoshida Y, Ng TL, Toffanin S, O'Sullivan M, Lu J, Phillips LA, Lockhart VL, et al. 2009. Lin 28 promotes transformation and is associated with advanced human malignancies. Nat Genet 41: 843-848.

Vujanic GM, Sandstedt B, Harms D, Kelsey A, Leuschner I, de Kraker J. 2002. Revised International Society of Paediatric Oncology (SIOP) working classification of renal tumors of childhood. Med Pediatr Oncol 38: 79-82.

West JA, Viswanathan SR, Yabuuchi A, Cunniff K, Takeuchi A, Park IH, Sero JE, Zhu H, Perez-Atayde A, Frazier AL, et al. 2009. A role for Lin 28 in primordial germ-cell development and germ-cell malignancy. Nature 460: 909-913.

Yu J, Vodyanik MA, Smuga-Otto K, Antosiewicz-Bourget J, Frane JL, Tian S, Nie J, Jonsdottir GA, Ruotti V, Stewart R, et al. 2007. Induced pluripotent stem cell lines derived from human somatic cells. Science 318: 1917-1920.

Zhou B, Ma Q, Rajagopal S, Wu SM, Domian I, Rivera-Feliciano J, Jiang D, von Gise A, Ikeda S, Chien KR, et al. 2008. Epicardial progenitors contribute to the cardiomyocyte lineage in the developing heart. Nature 454: 109-113.
Zhu H, Shah S, Shyh-Chang N, Shinoda G, Einhorn WS, Viswanathan SR, Takeuchi A, Grasemann C, Rinn JL, Lopez MF, et al. 2010. Lin28a transgenic mice manifest size and puberty phenotypes identified in human genetic association studies. Nat Genet 42: 626-630.

Zhu H, Shyh-Chang N, Segrè AV, Shinoda G, Shah SP, Einhorn WS, Takeuchi A, Engreitz JM, Hagan JP, Kharas MG, et al. 2011. The Lin28/let-7 axis regulates glucose metabolism. Cell 147: 81-94. 


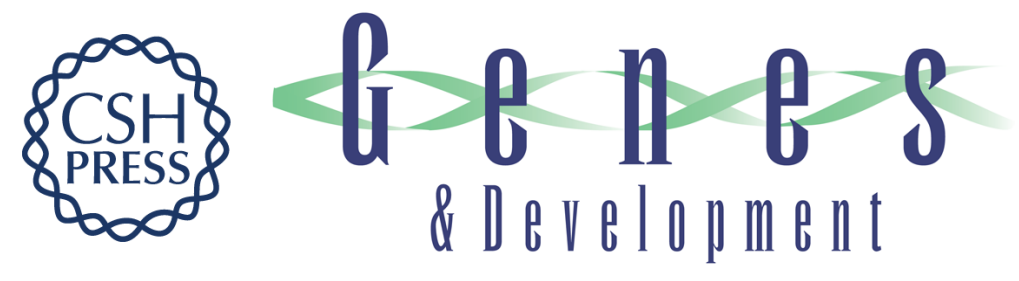

\title{
Lin28 sustains early renal progenitors and induces Wilms tumor
}

Achia Urbach, Alena Yermalovich, Jin Zhang, et al.

Genes Dev. 2014, 28: originally published online April 14, 2014

Access the most recent version at doi:10.1101/gad.237149.113

\author{
Supplemental http://genesdev.cshlp.org/content/suppl/2014/04/07/gad.237149.113.DC1 \\ Material \\ Related Content \\ LINking microRNAs, kidney development, and Wilms tumors \\ Peter Hohenstein and Nicholas D. Hastie \\ Genes Dev. May , 2014 28: 923-925
}

References This article cites 56 articles, 13 of which can be accessed free at: http://genesdev.cshlp.org/content/28/9/971.full.html\#ref-list-1

Articles cited in: http://genesdev.cshlp.org/content/28/9/971.full.html\#related-urls

Creative This article is distributed exclusively by Cold Spring Harbor Laboratory Press for the first Commons six months after the full-issue publication date (see

License http://genesdev.cshlp.org/site/misc/terms.xhtml). After six months, it is available under a Creative Commons License (Attribution-NonCommercial 4.0 International), as described at http://creativecommons.org/licenses/by-nc/4.0/.

Email Alerting Receive free email alerts when new articles cite this article - sign up in the box at the top Service right corner of the article or click here.

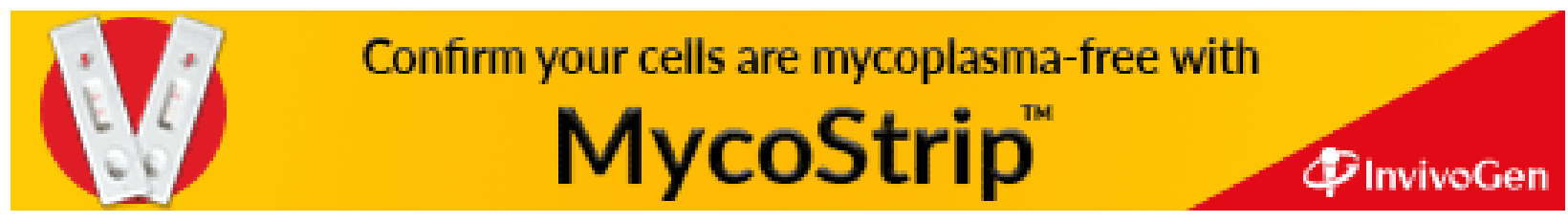

